\title{
Resistance to Antibiotics of Bacteria Isolated from Pets
}

\section{Rocío Pérez-y-Terrón ${ }^{1 *}$, Dulce Carolina Rodríguez-Robles², María Elena Pérez-Terrón ${ }^{3}$ and José Antonio Rivera-Tapia ${ }^{4}$}

${ }^{1}$ Faculty of Biological Sciences, BUAP, Mexico

${ }^{2}$ Bachelor of Biology, BUAP, Mexico

${ }^{3}$ Faculty of Management, BUAP, Mexico

${ }^{4}$ Institute of Science, BUAP, Mexico

*Corresponding Author: Rocío-Pérez y-Terrón, Research Professor, Faculty of Biological Sciences, Autonomous University of Puebla, Mexico.
Received: February 28, 2020

Published: March 03, 2020

(C) All rights are reserved by Rocío Pérez-yTerrón., et al.

\section{Abstract}

13 strains from previously isolated and identified domestic pets, Chryseobacterium, Citrobacter, Enterobacter, Hafnia, Klebsiella, Morganella, Pantoea, Photobacterium, Pleisomonas, Pseudomonas, Salmonella, Serratia and Vibrio were analyzed. Tricanged antibiograms of each strain were performed, with respect to the conventional method called Kirby Bauer, to observe the susceptibility by disc diffusion of each of them with 16 antibiotics of which as a result the following was obtained sensitivity to the total strains analysed; Cefotaxima with 46\%, Metronidazole 53\%, Dicloxacillin 38\%, Cephaxine 30\%, Ciprofloxacin 100\%, Nitrofurantoin 92\%, Erythromycin, Amoxicillin 100\%, Trimethoprim-Sulfalmetoxazole 100\%, Cephalotin 53\%, Gentamicin 100\%, Amikacin 100\%, Ceftriaxone 61\%, Benzipenicillin 31\%, Ampicillin 100\%, Erythromycin 69\%, Chloramphenicol 100\%. Also resulting in Photobacterium being the genus of bacteria that exhibited the most resistance.

Keywords: Bacteria; Pet; Antibiotic; Sensitivity; Resistance

\section{Abbreviations}

RPM: Revolutions Per Minute; $\mu$ L: Microliters; CFU: Colony Forming Units

\section{Introduction}

Medicines have always been an important component of man's life and within the broad spectrum of medicines are antibiotics [1]. The discovery of penicillin in 1927 by Alexander Fleming marked the beginning of the antibiotic era. The emergence of this drug encouraged the scientific community to develop endless antibiotics. This great discovery suggested that it was the beginning of the end of infectious diseases, which for their effectiveness, have been used for almost a century to control many diseases [2,3]. However, antimicrobial resistance to these drugs has been increasing due to intensive and excessive use of their consumption [4]. In contrast, bacteria are able to quickly develop mechanisms, which allow them to evade the effects of antibiotics, as it is ultimately an inevitable consequence of the evolutionary process of life [5].

Diseases that are transmitted from animals to humans can be caused by parasites, fungi, viruses and bacteria, reaching for locality either on your skin, gonads, limbs or almost any part of your body [6]. These pathogens can become resistant to various types of antibiotics. It is estimated that more than $4 \%$ of the problems of antimicrobial resistance in humans are closely related to animal sources, regardless of the antimicrobial resistance that develops in agriculture and livestock [7]. The impact of irrational use of antibiotics increases expenditure spending within health services and poses a risk to society, as it could lead to higher mortality from infectious diseases [8]. 
In our country there is little detailed information on the analysis of patients taking infections caused by pet-isolated pathogenic microorganisms, as well as their antibiotic susceptibility, whose knowledge helps to avoid a possible failure cause one of the most pressing public health problems worldwide, bacterial resistance. Therefore, our study is based on determining the resistance or sensitivity to different types of antibiotics of pathogenic bacteria isolated from pets.

\section{Materials and Methods}

51 strains listed in table 1 previously isolated from domestic pet feces (dogs, cats and turtles) were used, fentypically identified by Biochemical testing of the Biomérieux API20E system. A total of 13 genera are included, each of which underwent resistance tests with different types of commonly used antibiotics in the public health sector. Each of the strains was made three replicates, using the methodology of diffusion in agar with sensidisco (Kirby Bauer). The antibiotics used are listed in table 2.

Tests were included for the 7 different groups of antibiotics (beta-lactams, aminoglycosides, macrolides, amphenicoles, quinolones, sulfamides, nitroimidazoles and nitrofurans, with a total of 16 different antibiotics. Each was diluted from its initial commercial concentration, in $1.0 \mathrm{ml}$ of sterile distilled water, placed in a $1.5 \mathrm{ml}$ eppendorff tube.

The strains were sown in the culture medium liquid LB incubation for a period of 24 hours, at a temperature of $27^{\circ} \mathrm{C}$, in constant agitation of 100 revolutions per minute. Subsequently, serial dilutions were made up to $10-8$, one of these were placed $2 \mu \mathrm{l}$ each in a Petri box with solidified LB medium or incubating at $27^{\circ} \mathrm{C}$ for

\begin{tabular}{|c|c|}
\hline Bacterian Genus & Strains \\
\hline 1. Chryseobacterium indologenes & 35 \\
\hline 2. Citrobacter bactrim & 36 \\
\hline 3. Enterobacter aerogenes & $31 \mathrm{~b}$ \\
\hline 4. Hafnia alvei & $5,32 a, 41 a, 41 b$ \\
\hline 5. Klebsiella oxytoca & $40 \mathrm{~b}, 42,50^{\mathrm{a}}$ \\
\hline 6. Klebsiella pneumoniae & 24,33 \\
\hline 7. Morganella morganii & $28,31 \mathrm{a}, 44,46^{\mathrm{a}}$ \\
\hline 8. $\quad$ Pantoea sp. & $49,50 \mathrm{~b}, 12$ \\
\hline 9. Photobacterium & $8 b, 9,32 b, 47 b$ \\
\hline 10. Photobacterium damselae & $38^{\mathrm{a}}$ \\
\hline 11. Plesiomonas shigelloides & $46 \mathrm{~b}$ \\
\hline 12. Pseudomonas aeruginosa & $38 b, 38 c, 43 b$ \\
\hline 13. Pseudomonas sp. & $48 \mathrm{~b}$ \\
\hline 14. Salmonella colera suis & 26,29 \\
\hline 15. Serratia marcescens & $8 a, 25,30 a, 34 a, 47 a$ \\
\hline 16. Vibrio vulnificus & $\begin{array}{c}1 \mathrm{c}, 1 \mathrm{a}, 1 \mathrm{~b}, 2,30 \mathrm{~b}, 34 \mathrm{~b}, \\
37 \mathrm{a}, 37 \mathrm{~b}, 39,40^{\mathrm{a}}, 48^{\mathrm{a}}, 51 \mathrm{a}\end{array}$ \\
\hline
\end{tabular}

Table 1: Bacterial genera analyzed.

\begin{tabular}{|ll|l|}
\hline \multicolumn{2}{|l|}{ Antibiotics } & Disc Concentration \\
\hline 1. & Cefotaxim & $1 \mathrm{~g} / 1 \mathrm{ml}$ \\
\hline 2. & Dicloxacillin & $500 \mathrm{mg} / 1 \mathrm{ml}$ \\
\hline 3. & Cefalexim & $500 \mathrm{mg} / 1 \mathrm{ml}$ \\
\hline 4. & Ciprofloxacin & $250 \mathrm{mg} / 1 \mathrm{ml}$ \\
\hline 5. & Nitrofurantoin & $100 \mathrm{mg} / 1 \mathrm{ml}$ \\
\hline 6. & Erythromycin & $500 \mathrm{mg} / 1 \mathrm{ml}$ \\
\hline 7. & Amoxicillin & $500 \mathrm{mg} / 1 \mathrm{ml}$ \\
\hline 8. & Trimethoprim & $800 \mathrm{mg} / 1 \mathrm{ml} / 4000 \mathrm{mg} / 1 \mathrm{ml}$ \\
\hline & -sulfamethoxazole & \\
\hline 9. & Cephalotin & $1 \mathrm{~g} / 1 \mathrm{ml}$ \\
\hline 10. & Gentamicin & $80 \mathrm{ml} / 2 \mathrm{ml}$ \\
\hline 11. & Amikacin & $50 \mathrm{mg} / 2 \mathrm{ml}$ \\
\hline 12. & Ceftriaxone & $250 \mathrm{mg} / 2 \mathrm{ml}$ \\
\hline 13. & Benzipenicillin & $1,20000 \mathrm{U} / 1 \mathrm{ml}$ \\
\hline 14. & Metronidazole & $500 \mathrm{mg} / 1 \mathrm{ml}$ \\
\hline 15. & Chloramphenicol & $5 \mathrm{ml} / 1 \mathrm{ml}$ \\
\hline 16. & Ampicillin & $500 \mathrm{mg}$ \\
\hline
\end{tabular}

Table 2: Antibiotics used for Sensitivity Test.

24 hours. The visibly separated CFUs were counted by locating the corresponding dilution, allowing to calculate the number of CFUs per ml. A spectrophotometer marked Themoscientific Genesys 20 was used with an absorbance of $625 \mathrm{~nm}$ and UFM sms per ml were calculated for each strain in order to refer to the concentration of cells present in the inoculum. It was subsequently adjusted to the $10-7 \mathrm{CFU} / \mathrm{ml}$ amount of each strain that underwent an antibiogram.

The Muller-Hinton médium was prepared. It is recognized that until now it has been a universally recommended culture medium for antimicrobial sensitivity testing. It was sterilized for 20 minutes in the autoclave at $15 \mathrm{lbs}$ of pressure, then placed in Petri boxes, filling them to $4 \mathrm{~mm}$ wide, corresponding to $25 \mathrm{ml}$ of agar for each.

Filter paper discs, each $6 \mathrm{~mm}$ in diameter, were used for the Kirby-Bauer test, which were sterilized at $12^{\circ} \mathrm{C}$ for 20 minutes, then sterilized infertility-proof for 24 hours. The plates were massively sown with sterile cotton swab. The filter paper discs were then supplied with the impregnated antibiotic in the paper discs. 4 or 5 discs were used per Petri dish leaving a space of $5 \mathrm{~cm}$ between each. The plates inoculated and with the discs that were applied, were inverted incubated at an ambient temperature of $27^{\circ} \mathrm{C}$ for a period of 24 hours.

The plate was read after incubation, with a Vernier brand Mitutoyo, taking as reference the diameter of the inhibition halo. Two categories of interpretation were considered: 
- Sensitive: Presents halo inhibiting the growth of the bacteria around the sensidisco.

- Resistant: It is called resistant when the strains are not inhibited and therefore do not have inhibition halo. They are not inhibited by the antibiotic. The results were reported in tables and graphs of inhibition.

\section{Results and Discussion}

After 24 hours of incubation, the measurement of the inhibition halos produced by each antibiotic and strain was performed. The following tables analyze the averages of the diameters of inhibitions produced by each antibiotic for each bacterial genus.

Table 3 shows that all bacterial genera were sensitive to aminoglycosides: amikacin and gentamicin, the genus Citrobacter shows greater sensitivity to these antibiotics $29.42 \mathrm{~mm}$ and $33.31 \mathrm{~mm}$ respectively, in accordance with that of these antibiotics $29.42 \mathrm{~mm}$ and $33.31 \mathrm{~mm}$ respectively, in accordance with that of Citrobacter shows up to $100 \%$ sensitivity to Gentamicin and Amikacin [9]. In contrast, the lowest resistance level was presented in Photobacterium with a value of $14.53 \mathrm{~mm}$ for Gentamicin.

All bacterial genera were sensitive to Amoxicillin, while for bencipenicillin the sensitivity was $30 \%$, equal for cefalexin and $53 \%$ for cephalotin. The genus Photobacterium was resistant to these three antibiotics, while Plesiomonas and Morganella were resistant to cefalexin. It is also observed that all bacterial genera were sensitive to ampicillin (100\%), and for Ceftriaxone has a sensitivity of $61 \%$, Serratia and Citrobacter were resistant. While for Cefotaxima they were sensitive $46 \%$ being resistant Vibrio and Citrobacter,

\begin{tabular}{|l|l|l|l|l|l|}
\hline & \multicolumn{3}{|l|}{ Aminoglycosides } & & \\
\hline Genus & \multicolumn{2}{|l|}{ Inhibition Halos Size } & \\
\hline & Amikacin & * & Gentamicin & * \\
\hline Hafnia & 28.05 & $\mathrm{~s}$ & 30.37 & $\mathrm{~s}$ \\
\hline Serratia & 28.58 & $\mathrm{~s}$ & 27.69 & $\mathrm{~s}$ \\
\hline Plesiomonas & 25.48 & $\mathrm{~s}$ & 26.2 & $\mathrm{~s}$ \\
\hline Chryseobacterium & 24.89 & $\mathrm{~s}$ & 31.37 & $\mathrm{~s}$ \\
\hline Klebsiella & 28.66 & $\mathrm{~s}$ & 28.9 & $\mathrm{~s}$ \\
\hline Enterobacter & 27.69 & $\mathrm{~s}$ & 29.3 & $\mathrm{~s}$ \\
\hline Salmonella & 28.04 & $\mathrm{~s}$ & 28.1 & $\mathrm{~s}$ \\
\hline Pantoea & 25.08 & $\mathrm{~s}$ & 26.59 & $\mathrm{~s}$ \\
\hline Vibrio & 25.48 & $\mathrm{~s}$ & 30.23 & $\mathrm{~s}$ \\
\hline Citrobacter & 29.42 & $\mathrm{~s}$ & 33.31 & $\mathrm{~s}$ \\
\hline Pseudomonas & 28.66 & $\mathrm{~s}$ & 31.93 & $\mathrm{~s}$ \\
\hline Photobacterium & 26.53 & $\mathrm{~s}$ & 14.53 & $\mathrm{~s}$ \\
\hline Morganella & 25.73 & $\mathrm{~s}$ & 27.32 & $\mathrm{~s}$ \\
\hline S & $17 \mathrm{~mm}$ & $100 \%$ & $15 \mathrm{~mm}$ & $100 \%$ \\
\hline I & $15-16 \mathrm{~mm}$ & & $13-14 \mathrm{~mm}$ & \\
\hline R & $14 \mathrm{~mm}$ & & $12 \mathrm{~mm}$ & \\
\hline
\end{tabular}

Table 3: Average aminoglycoside inhibition halos for all bacterial genera *S means sensitive; I stands for intermediate sensitivity and R means resistant.

for Dicloxacillin they were sensitive 38\%, among which were resistant were Hafnia, Serratia, hryseobacterium, Enterobacter, Vibrio, Citrobacter and Photobacterium.

\begin{tabular}{|c|c|c|c|c|c|c|c|c|c|c|c|c|c|c|c|c|}
\hline & & Beta- & Lactam & & & & & & & & & & & & & \\
\hline & Inhibition 1 & Ialos S & & & & & & & & & & & & & & \\
\hline & $\begin{array}{l}\text { Benzipen- } \\
\text { icillin }\end{array}$ & & $\begin{array}{l}\text { Amoxi- } \\
\text { cillin }\end{array}$ & & $\begin{array}{l}\text { Cefalex- } \\
\text { im }\end{array}$ & & $\begin{array}{l}\text { Cepha- } \\
\text { lotin }\end{array}$ & & $\begin{array}{l}\text { Diclox- } \\
\text { acillin }\end{array}$ & & $\begin{array}{l}\text { Cefotax- } \\
\text { ima }\end{array}$ & & $\begin{array}{l}\text { Ampi- } \\
\text { cillin }\end{array}$ & & $\begin{array}{l}\text { Ceftri- } \\
\text { axone }\end{array}$ & \\
\hline Hafnia & 12.83 & $\mathrm{R}$ & 19.32 & $S$ & 27.7 & S & 25.42 & S & 0 & $\mathrm{R}$ & 21.38 & $\mathrm{R}$ & 27.5 & S & 17.63 & $\mathrm{R}$ \\
\hline Serratia & 14.78 & $\mathrm{R}$ & 22.03 & $S$ & 27.13 & $S$ & 20.45 & $\mathrm{~S}$ & 0 & $\mathrm{R}$ & 17.57 & $\mathrm{R}$ & 25 & $\mathrm{~S}$ & 12.59 & $\mathrm{R}$ \\
\hline Plesiomonas & 14.93 & $\mathrm{R}$ & 27.52 & $\mathrm{~S}$ & 0 & $\mathrm{R}$ & 14.52 & $\mathrm{R}$ & 19.62 & S & 37.01 & $S$ & 27.5 & $\mathrm{~S}$ & 33.34 & $\mathrm{~S}$ \\
\hline $\begin{array}{l}\text { Chryseobacte- } \\
\text { rium }\end{array}$ & 11.14 & $\mathrm{R}$ & 22.64 & $S$ & 19.22 & S & 13.52 & $\mathrm{R}$ & 0 & $\mathrm{R}$ & 36.82 & S & 40.3 & S & 26.29 & $S$ \\
\hline Klebsiella & 15.1 & $\mathrm{R}$ & 29.35 & $S$ & 29.34 & S & 25.66 & $S$ & 15.03 & $\mathrm{R}$ & 20.35 & $\mathrm{R}$ & 37.5 & S & 16.43 & $\mathrm{R}$ \\
\hline Enterobacter & 22.46 & $S$ & 29.6 & S & 30.32 & S & 20.14 & S & 0 & $\mathrm{R}$ & 19.98 & $\mathrm{R}$ & 39 & $S$ & 31.09 & $S$ \\
\hline Salmonella & 19.23 & $\mathrm{R}$ & 26.23 & S & 24.97 & S & 16.83 & $\mathrm{R}$ & 19.9 & S & 37.79 & $S$ & 35.5 & $S$ & 35.1 & $\mathrm{~S}$ \\
\hline Pantoea & 27.1 & $S$ & 33.01 & $S$ & 29.58 & $S$ & 24.53 & S & 21.7 & S & 39.42 & $S$ & 37.5 & $\mathrm{~S}$ & 36.76 & $\mathrm{~S}$ \\
\hline Vibrio & 15.45 & $\mathrm{R}$ & 26.92 & $S$ & 27.41 & $\mathrm{~S}$ & 17.5 & $\mathrm{R}$ & 0 & $\mathrm{R}$ & 14.86 & $\mathrm{R}$ & 36.12 & $\mathrm{~S}$ & 15.1 & $\mathrm{R}$ \\
\hline Citrobacter & 14.2 & $\mathrm{R}$ & 28.35 & S & 23.62 & $\mathrm{~S}$ & 15.8 & $\mathrm{R}$ & 0 & $\mathrm{R}$ & 14 & $\mathrm{R}$ & 41.3 & $\mathrm{~S}$ & 12.63 & $\mathrm{R}$ \\
\hline Pseudomonas & 22.12 & S & 21.4 & S & 32.83 & S & 21.36 & S & 18.9 & S & 31.39 & S & 23 & $\mathrm{~S}$ & 35.01 & $\mathrm{~S}$ \\
\hline Photobacterium & 0 & $\mathrm{R}$ & 24.37 & $\mathrm{~S}$ & 0 & $\mathrm{R}$ & 0 & $\mathrm{R}$ & 0 & $\mathrm{R}$ & 22.17 & $\mathrm{R}$ & 27.2 & $\mathrm{~S}$ & 33.43 & $\mathrm{~S}$ \\
\hline Morganella & 21.25 & S & 28.13 & S & 0 & $\mathrm{R}$ & 18.69 & $S$ & 17.5 & S & 34.72 & S & 32 & S & 35.18 & $S$ \\
\hline$S$ & $21 \mathrm{~mm}$ & $30 \%$ & $18 \mathrm{~mm}$ & $100 \%$ & $18 \mathrm{~mm}$ & $30 \%$ & $18 \mathrm{~mm}$ & $53 \%$ & $13 \mathrm{~mm}$ & $38 \%$ & $23 \mathrm{~mm}$ & $46 \%$ & $17 \mathrm{~mm}$ & $100 \%$ & $21 \mathrm{~mm}$ & $61 \%$ \\
\hline I & $18-20 \mathrm{~mm}$ & & $\begin{array}{l}14- \\
17 \mathrm{~mm}\end{array}$ & & $15-17 \mathrm{~mm}$ & & $\begin{array}{l}15- \\
17 \mathrm{~mm}\end{array}$ & & $\begin{array}{l}11- \\
12 \mathrm{~mm}\end{array}$ & & $15-22 \mathrm{~mm}$ & & $\begin{array}{l}14- \\
16 \mathrm{~mm}\end{array}$ & & $\begin{array}{l}14- \\
20 \mathrm{~mm}\end{array}$ & \\
\hline $\mathrm{R}$ & $17 \mathrm{~mm}$ & & $13 \mathrm{~mm}$ & & $14 \mathrm{~mm}$ & & $14 \mathrm{~mm}$ & & $10 \mathrm{~mm}$ & & $14 \mathrm{~mm}$ & & $13 \mathrm{~mm}$ & & $13 \mathrm{~mm}$ & \\
\hline
\end{tabular}

Table 4: Average of Beta-lactam inhibition halos for all bacterial genera. 
Table 5 shows the bacterial genera that were resistant to macrolides among these are: Hafnia, Serratia, Vibrio and the genus that showed the most resistance is Photobacterium, with the measurement of $10.94 \mathrm{~mm}$ a halo less than all. While the genus showing the greatest sensitivity was Chyseobacterium, since the measure of the halo is $30.82 \mathrm{~mm}$.

\begin{tabular}{|c|c|c|}
\hline & Macrolide & \\
\hline & \multicolumn{2}{|c|}{ Inhibition Halos Size } \\
\hline & Erythromycin & \\
\hline Hafnia & 17.8 & $\mathrm{R}$ \\
\hline Serratia & 16.5 & $\mathrm{R}$ \\
\hline Plesiomonas & 18.55 & $\mathrm{~S}$ \\
\hline Chryseobacterium & 30.82 & $\mathrm{~S}$ \\
\hline Klebsiella & 22.05 & S \\
\hline Enterobacter & 25.19 & $\mathrm{~S}$ \\
\hline Salmonella & 25.95 & S \\
\hline Pantoea & 25.69 & $\mathrm{~S}$ \\
\hline Vibrio & 15.95 & $\mathrm{R}$ \\
\hline Citrobacter & 19.5 & $\mathrm{~S}$ \\
\hline Pseudomonas & 28.58 & $\mathrm{~S}$ \\
\hline Photobacterium & 10.94 & $\mathrm{R}$ \\
\hline Morganella & 23.75 & $\mathrm{~S}$ \\
\hline S & $18 \mathrm{~mm}$ & $69 \%$ \\
\hline I & $14-17 \mathrm{~mm}$ & \\
\hline $\mathrm{R}$ & $13 \mathrm{~mm}$ & \\
\hline
\end{tabular}

Table 5: Average macrolide inhibition halos for all bacterial genera.

The genus Photobacterium shows resistance to Erythromycin, as in studies of isolated bacteria in different environments of different soils in orchards treated with manure fertilizer, the bacterial susceptibility of these soils is highly resistant to Erythromycin [10]. Table 5 shows a very similar result of resistance in Photobacterium to Erythromycin with a diameter of $10.94 \mathrm{~mm}$.

In Table 6 the bacterial genera presented are 100\% sensitive to chloramphenicol. In the case of Klebsiella the largest inhibition halo of $35.5 \mathrm{~mm}$ was found, while the smaller was Pseudomonas with $22.5 \mathrm{~mm}$.

Studies in Brazil isolated bacteria from oral cavities to the family Enterobacteriaceae and Pseudomonadaceae which were per-

\begin{tabular}{|c|c|c|}
\hline & Anfenicol & \\
\hline & \multicolumn{2}{|c|}{ Inhibition Halos Size } \\
\hline & Chloramphenicol & \\
\hline Hafnia & 26.5 & $S$ \\
\hline Serratia & 29 & $S$ \\
\hline Plesiomonas & 28.5 & $S$ \\
\hline Chryseobacterium & 31.6 & S \\
\hline Klebsiella & 35.5 & $S$ \\
\hline Enterobacter & 22.5 & $\mathrm{~S}$ \\
\hline Salmonella & 25.5 & S \\
\hline Pantoea & 29 & S \\
\hline Vibrio & 34 & $\mathrm{~S}$ \\
\hline Citrobacter & 29.6 & $S$ \\
\hline Pseudomonas & 22.5 & $S$ \\
\hline Photobacterium & 27.5 & $\mathrm{~S}$ \\
\hline Morganella & 34 & $\mathrm{~S}$ \\
\hline S & $18 \mathrm{~mm}$ & $100 \%$ \\
\hline I & $13-17 \mathrm{~mm}$ & \\
\hline $\mathrm{R}$ & $12 \mathrm{~mm}$ & \\
\hline
\end{tabular}

Table 6: Average of Anfenicoles inhibition halos for all bacterial genera.

formed as antimicrobial susceptibility, resulting in all Enterobacteria including two species of Klebsiella as they are K. pneumonae and $K$. oxytoca obtained in this study were sensitive to chloramphenicol, while with Pseudomonas showed some resistance to this antibiotic but sensibly to Ciprofloxacin and Chloramphenicol $[11,12]$.

Table 7 shows $100 \%$ sensitivity of bacterial genera to Ciprofloxacin. All strains comply with the standard measures according to Kirby Bauer because for bacteria to be sensitive to this antibiotic, they must have an inhibition halo of $21 \mathrm{~mm}$. In our results, the lowest halo size was for Photobacterium with $29.79 \mathrm{~mm}$, while for Pseudomonas the halo was the largest of all with $46.63 \mathrm{~mm}$.

The bacterial genera in table 8 show $100 \%$ sensitivity to Trimethoprim -sulfamethoxazole although they all have sensitivity, you can check in Vibrio has greater sensitivity $39.5 \mathrm{~mm}$ and that it is the best antibiotic for this bacterium (global health organization), it is worth while note that the least sensitive was Serratia with a halo of $27.81 \mathrm{~mm}$. The antimicrobial agent that remains suitable for Vibrio par excellence is Trimethoprim - sulfamethoxazole, according to records maintained since 2002 by global health organization. 


\begin{tabular}{|c|c|c|}
\hline & Quinolone & \\
\hline & \multicolumn{2}{|c|}{ Inhibition Halos Size } \\
\hline & Ciprofloxacin & \\
\hline Hafnia & 39.44 & $\mathrm{~S}$ \\
\hline Serratia & 34.03 & $\mathrm{~S}$ \\
\hline Plesiomonas & 37.34 & $\mathrm{~S}$ \\
\hline Chryseobacterium & 42.62 & $\mathrm{~S}$ \\
\hline Klebsiella & 39.67 & $\mathrm{~S}$ \\
\hline Enterobacter & 40.66 & $\mathrm{~S}$ \\
\hline Salmonella & 41.04 & $\mathrm{~S}$ \\
\hline Pantoea & 36.57 & $\mathrm{~S}$ \\
\hline Vibrio & 31.18 & $\mathrm{~S}$ \\
\hline Citrobacter & 35.42 & $\mathrm{~S}$ \\
\hline Pseudomonas & 46.63 & $\mathrm{~S}$ \\
\hline Photobacterium & 29.79 & $\mathrm{~S}$ \\
\hline Morganella & 32.82 & $\mathrm{~S}$ \\
\hline$S$ & $21 \mathrm{~mm}$ & $100 \%$ \\
\hline I & $16-20 \mathrm{~mm}$ & \\
\hline $\mathrm{R}$ & $15 \mathrm{~mm}$ & \\
\hline
\end{tabular}

Table 7: Average Quinolone inhibition halos for all bacterial genera.

\begin{tabular}{|c|c|c|}
\hline & Sulfamide & \\
\hline & \multicolumn{2}{|c|}{ Inhibition Halos Size } \\
\hline & \multicolumn{2}{|c|}{ Trimethoprim -sulfamethoxazole } \\
\hline Hafnia & 28.42 & S \\
\hline Serratia & 27.81 & S \\
\hline Plesiomonas & 30.91 & S \\
\hline Chryseobacterium & 35.12 & S \\
\hline Klebsiella & 32.14 & $\mathrm{~S}$ \\
\hline Enterobacter & 35.04 & S \\
\hline Salmonella & 32.95 & S \\
\hline Pantoea & 35.11 & S \\
\hline Vibrio & 39.5 & $S$ \\
\hline Citrobacter & 34.76 & S \\
\hline Pseudomonas & 23.9 & S \\
\hline Photobacterium & 32.1 & S \\
\hline Morganella & 29.92 & S \\
\hline$S$ & $16 \mathrm{~mm}$ & $100 \%$ \\
\hline I & $11-15 \mathrm{~mm}$ & \\
\hline $\mathrm{R}$ & $10 \mathrm{~mm}$ & \\
\hline
\end{tabular}

Table 8: Average Sulfamide inhibition halos for all bacterial genera.

Table 9 results in a total percentage of 53\% sensitivity of bacterial genera to the antibiotic Metronidazole, among the resistant bacterial genera we can find Plesiomonas, Chryseobacterium, Hafnia, Pantoea, Pseudomonas, Citrobacter being the latter that did not have a halo of inhibition unlike those already indicated. the

genera that had the highest sensitivity were Serratia, Enterobacter, Salmonella, Vibrio, Photobacterium, Morganella, Klebsiella was the one that had the greatest antibiotic sensitivity unlike the others, presenting a halo of $34.5 \mathrm{~mm}$.

\begin{tabular}{|c|c|c|}
\hline & Nitroimidazole & \\
\hline & \multicolumn{2}{|c|}{ Inhibition Halos Size } \\
\hline & Metronidazole & \\
\hline Hafnia & 16 & $\mathrm{R}$ \\
\hline Serratia & 29.9 & $S$ \\
\hline Plesiomonas & 14 & $\mathrm{R}$ \\
\hline Chryseobacterium & 15 & $\mathrm{R}$ \\
\hline Klebsiella & 34.5 & $S$ \\
\hline Enterobacter & 18 & S \\
\hline Salmonella & 26 & S \\
\hline Pantoea & 13 & $\mathrm{R}$ \\
\hline Vibrio & 33.5 & $S$ \\
\hline Citrobacter & 0 & $\mathrm{R}$ \\
\hline Pseudomonas & 16 & $\mathrm{R}$ \\
\hline Photobacterium & 28 & $S$ \\
\hline Morganella & 25 & $S$ \\
\hline S & $18 \mathrm{~mm}$ & $53 \%$ \\
\hline I & & \\
\hline $\mathrm{R}$ & $17 \mathrm{~mm}$ & \\
\hline
\end{tabular}

Table 9: Average inhibition halos of Nitroimidazoles for all bacterial genera.

\begin{tabular}{|c|c|c|}
\hline & Nitrofuran & \\
\hline & \multicolumn{2}{|c|}{ Inhibition Halos Size } \\
\hline & Nitrofurantoin & \\
\hline Hafnia & 16.93 & $S$ \\
\hline Serratia & 18.24 & S \\
\hline Plesiomonas & 15.95 & $\mathrm{R}$ \\
\hline Chryseobacterium & 17.89 & $S$ \\
\hline Klebsiella & 19.53 & $S$ \\
\hline Enterobacter & 23.59 & S \\
\hline Salmonella & 23.76 & $S$ \\
\hline Pantoea & 23.15 & $S$ \\
\hline Vibrio & 20.17 & $S$ \\
\hline Citrobacter & 21.62 & $S$ \\
\hline Pseudomonas & 30.43 & $S$ \\
\hline Photobacterium & 20.46 & $S$ \\
\hline Morganella & 35.91 & $S$ \\
\hline S & $17 \mathrm{~mm}$ & $92 \%$ \\
\hline I & $15-16 \mathrm{~mm}$ & \\
\hline $\mathrm{R}$ & $14 \mathrm{~mm}$ & \\
\hline
\end{tabular}

Table 10: Average Nitrofuran inhibition halos shown for all bacterial genera. 
One bacterium was resistant to Nitrofurantoin so as a final result $92 \%$ sensitivity was obtained against this antibiotic. The resistant bacterium was Pseudomonas with an inhibition halo of $15.95 \mathrm{~mm}$.

\section{Conclusion}

The bacterial genera analyzed in this study show increased sensitivity to Quinolones, Aminoglucosidics and Anfenicoles, while the genera show greater resistance are Betalactamics so it is noticeable that bacteria currently follow generating resistance mechanisms. It was possible to confirm along with the literature that the antibiotic Dicloxacillin has no favorable antimicrobial spectrum for Gram-negative bacteria. The genus of bacteria that showed the most resistance to the different groups of antibiotics was Photobacterium in addition to being a piscicid bacteria, we can find different types of sewage or also sea, rivers, and industrial waters.

\section{Acknowledgements}

The support provided by the Vice-Chancellor of Research and Postgraduate Studies of the Autonomous University of Puebla for the realization of this work is appreciated.

\section{Conflicts of Interest}

None.

\section{Bibliography}

1. Perez Ruben. "Veterinary Pharmacology". Chile: Teaching Directorate Workshops (2010).

2. Santos MLG. "Study of antibiotic resistance [beta]-lactalmic in clinical isolations of "Salmonella typhimurium". Madrid: Complutense University of Madrid (2002).

3. Belloso W. History of antibiotics". Buenos Aires: Clínica Hospital Italiano de Buenos Aires (2009).

4. Hives ME. "Proposal of Multidisciplinary Strategies with Pharmaceutical Intervention in the Use of Antimicrobials in Health Institutions". Granada, Spain (2013).

5. Rodriguez-Ganen 0 and J Asbun-Bojalil. "Surveillance of antimicrobial consumption in hospitals in Mexico: current situation and practical guidance for its implementation". Pan American Public Health 3.5 (2012): 381-387.

6. Antúnez AO and others. "Frequency of isolated pathogens in clinical cases of canine bacterial dermatitis and its antibiotic susceptibility". Lima, Peú: Faculty of Veterinary and Zootechnics, Universidad Peruana (2009).
7. Lloyd DH. Reservoirs of Antimicrobial Resistance in Pet Animals Clinical Infectious (2007).

8. Dresser A and others. Use of antibiotics in Mexico problem review and policies 50 (2008): 480-487.

9. Rincón JR Llanos and J Gómez. "Aminoglycosides in the new decade: their use in the practical clinic". Spanish Journal of Chemotherapy 13.4 (2000): 903-904.

10. Popowska M and others. "Influence of soil use on prevalence of tetracycline, streptomycin an erythromycin resistance and associated resistance genes". Antimicrobial Agents and Chemotheraphy 56.3 (2012): 1434-1443.

11. Santos MLG. "Study of antibiotic resistance [beta]-lactalmic in clinical isolations of "Salmonella typhimurium". Madrid: Complutense University of Madrid (2002).

12. Silva Castillo RO. "Isolation and identification of Pseudomonas spp and antimicrobial resistance pattern in reptiles in captivity". Quito: Quito: UCE, s.f.

\section{Assets from publication with us}

- Prompt Acknowledgement after receiving the article

- Thorough Double blinded peer review

- Rapid Publication

- Issue of Publication Certificate

- High visibility of your Published work

Website: https://www.actascientific.com/

Submit Article: https://www.actascientific.com/submission.php Email us: editor@actascientific.com

Contact us: +919182824667 